\title{
INTELLIGENCE AND ACADEMIC ACHIEVEMENT IN MATHEMATICS AT UNIVERSITY LEVEL: A STUDY OF STUDENTS' BELIEFS Sadaf $\mathrm{Naz}^{1^{*}}$, Muhammad Ilyas Khan ${ }^{2}$, Syed Afzal $\mathrm{Shah}^{3}$, Anjum Qayyum ${ }^{4}$
}

\author{
${ }^{1 *}$ Assistant Professor, Department of Education, Hazara University, Pakistan; ${ }^{2}$ Associate Professor, Department of
} Education, Hazara University, Pakistan; ${ }^{3}$ Assistant Professor, Department of Education, The University of Haripur, Pakistan;

${ }^{4}$ Lecturer, Department of Education, Hazara University, Pakistan.

Email: "sadafhu@yahoo.com

\author{
Article History: Received on $26^{\text {th }}$ February 2021, Revised on $9^{\text {th }}$ April 2021, Published on $22^{\text {nd }}$ April 2021
}

\begin{abstract}
Purpose of the study: The current study explored a possible association between students' beliefs about their intelligence and academic achievement and compared gender differences in terms of these two variables.

Methodology: The sample of the study comprised of four hundred and fifty (male and female) MSc mathematics students, randomly selected from seven public sector universities of Khyber Pakhtunkhwa, Pakistan. A scale developed by Dweck (1999) was adapted to collect data for this study. Academic achievement was measured through students' previous examination scores.

Findings: Findings of the study showed that male students believed more in 'incremental' intelligence and had significantly higher academic achievement as compared to their female counterparts. A significant relationship was found between students' beliefs in 'incremental' intelligence and their academic achievement.

Applications of the study: The study has important implications for teachers and academics in the subjects of science and mathematics. This study also has implications for policies planners and administration in terms of developing an understanding regarding the role of students' beliefs about intelligence and academic achievement. The study could lead to new thinking about ways to work on the beliefs of students that could result in better academic achievement.
\end{abstract}

The novelty of this study: The study could also lead to further studies regarding the role of gender in affecting incremental beliefs and academic achievement.

Keywords: Academic Achievement, Gender Differences, Incremental Ability, Intelligence Beliefs.

INTRODUCTION AND BACKGROUND

Beliefs are recognized as people's inner acceptance of propositions which are formed through experiences (Ajzen, 2020). Beliefs influence a wide range of mental activities (de Jonge, Omran, Faulkner, \& Sabiston, 2020). Students have different beliefs about learning, and these beliefs have an impact on the interpretation of information and understanding in the real-life context (Tondeur, Van Braak, Ertmer, \& Ottenbreit-Leftwich, 2017). Students' beliefs about the role and nature of intelligence in educational achievement have been considered very important. Todor, (2014) introduced the implicit theory of intelligence which is constructed on two opposite beliefs about intelligence. First, the 'entity' beliefs are related to the idea that intelligence is a fixed 'entity' that cannot be altered (Hughes, 2015). The second one is the 'incremental' beliefs which postulate that intelligence can be changed through individual hard work, efforts, and diligence (Wren, \& Bedeian, 2020). According to Thomas, and Sarnecka, (2015) individuals can be grouped into these two categories fixed ('entity') or malleable ('incremental'). Kassaee, (2016) argues that students have different beliefs about ability; some believe in the 'entity theory of intelligence while others believe that it is a dynamic and malleable construct. Students favouring an 'entity' view keep themselves busy with learning for the self-projection of their capabilities, to get credit from teachers, parents and to waive off criticism for failing to get a better position in the class (Price, 2021).

Chen, and Wong, (2015) argue that learners who follow the 'incremental' theory of intelligence are better oriented for learning. Such students show more eagerness to have the knowledge and improve their efficiency to develop their talents (Hava, Guyer, \& Cakir, 2020). They are inspired and energized in attempting challenging tasks and applying new techniques (Barkley, \& Major, 2020).

An 'incremental' view of intelligence improves academic performance and promotes better attitudes towards learning (Claro, Paunesku, \& Dweck, 2016). Claro, et al., (2016) found that students who believe in an 'incremental' intelligence often have better performance than those students who believe in an 'entity' intelligence at every socioeconomic level. It has also been identified that students having an 'incremental' view are more persistent in education. These students are more eager to accept challenges and attain better outcomes (Renaud-Dubé, et al., 2015). 
Gender has been identified as a common focus in education throughout the years, but as society developed females become more equal with males in the workforce. Besides, attitude towards intelligence, gender has been the main player in the development and formation of beliefs about the nature of intelligence (Mundy, 2012). Despite progress towards more gender equality in different fields of life, females still have to catch up in fields such as science, technology, math, engineering, and aviation to name a few (Ferla, \& Graham, 2019). Several researchers show girls are more inclined towards the fixed abilities approach than boys particularly in mathematics and science (Thippana, Elliott, Gehman, Libertus, \& Libertus, 2020). Claro \& Loeb (2017) found that female students hold more 'incremental' beliefs about intelligence than male students.

The discussion above highlights the significance of students' beliefs about intelligence in terms of gender differences. The gender focus on this factor is also interesting and inconclusive and has not been much explored in the Pakistani context. Keeping in view the importance of gender differences in terms of beliefs regarding intelligence, the current study is an attempt to explore gender differences at a higher education level in the Pakistani context. This study, therefore, was conducted to examine a possible association between students' beliefs about intelligence and their academic achievement. The study also explored possible gender differences in students' academic achievement and their beliefs about intelligence. The study, therefore revolves around the following research questions:

i. What (if) any association is there between students' beliefs about the nature of intelligence and their academic achievement?

ii. What (if) any gender difference is there in students' beliefs about intelligence and academic achievement?

\section{LITERATURE REVIEW}

Students often enter into the class with different sets of beliefs (Eccles, \& Wigfield, 2020). Some students consider their intelligence as a fixed entity that cannot be changed. This is called an entity theory of intelligence (Dweck,1988). Many students usually believe that they cannot do much about changing their intelligence while students who believe in an incremental mindset think that their intelligence is flexible and can be changed or increased through efforts. This is termed the incremental theory of intelligence (Dweck,1988).

\section{Incremental and Entity beliefs about intelligence}

Vahalíková (2013) identifies different beliefs on the part of students regarding their intelligence. Students' beliefs about their intelligence can be divided into the entity and incremental beliefs (Moe, Hausmann, \& Hirnstein, 2021). The former is the belief that intelligence is changeable because it can be developed and improved with practice and efforts $\underline{\text { Lou, \& Noels, }}$ 2019). Such students believe in the constantly changing nature of skills and abilities (Savage, et al, 2018). In comparison, the second type of belief about intelligence is that it is a fixed entity that cannot be changed with efforts and practice (Mofield, \& Parker Peters, 2018). These beliefs have important effects on students' motivation and learning (Vincent-Ruz, \& Schunn, 2017).

Aydin, Ozfidan, and Carothers, (2017) argue that students of these two groups have different beliefs about "ability". If some students want to show off their ability according to them it is something static that exists in them, while others intended to enhance their ability, it feels dynamic and changeable. Implicit theories about intelligence have been deeply studied in terms of their outcome variables and the learning processes (OKeefe, Dweck, \& Walton, 2018). Implicit theories broadly deal with students' beliefs about intelligence that it is either static or something changeable or malleable (Hirsch, Bieleke, Schüler, \& Wolff, 2020). The two main conceptions of intelligence include taking it as a 'fixed' and as a 'changeable' entity (Hirsch, Bieleke, Schüler, \& Wolff, 2020). Students who believe in fixed intelligence seem to show poor performance to their lack of natural abilities in the relevant fields (van Aalderen-Smeets, \& van der Molen, 2018). This kind of conception often leads to face obstructions and result in negative emotions including hopelessness, shame, anger, and anxiety (De Castella \& Byrne $\underline{2015)}$.

Students with entity beliefs are restricted in their horizons in terms of thinking out of the box and aiming for extraordinary accomplishments (Brandon, Lombardi, \& Shen,2017). Such students often prefer to avoid difficult and challenging situations which often results in their low performance (Ortiz Alvarado, Rodriguez Ontiveros, \& Ayala Gaytán, 2019). Encountering hardships lead to disappointment and possible failure on the part of students (Lee, 2020). This often results in a negative effect on their outlook and ultimately on their aspirations for higher achievement (Redding, 2019). Faced with a complex situation they think it is their poor intelligence that leads to their failure (Mak, \& Pichika, 2019).

Since students who beliefs in incremental intelligence emphasize purposeful learning, the beliefs in the pattern of perfective response keep their intellectual development on a priority basis (Peng, \& Chen, 2019) and overcome difficulties through an enhanced effort in challenging situations. They believe that working hard is necessary (Tambe, Cappelli, \& Yakubovich, (2019). Such students believe that poor performances are directly proportionate to the effort, rather than an innate ability, 
show flexibility in the face of learning obstacles (Yeager, et al, 2019) and improve their future achievement by taking remedial actions (Haimovitz, \& Dweck, 2017).

Besides, students with 'incremental' thinking face lesser levels of anxiety (Rissanen, Kuusisto, Hanhimäki, \& Tirri, 2018). In difficult situations, such students mobilize their intellectual abilities to perform tasks with greater success as compared to their 'entity' peers (Kim, \& Jung, 2019). Such students also show greater resilience when faced with failures (Fitri, Syahputra, \& Syahputra, 2019). They show more interest in exploring new avenues for learning. These including strategies such as note-taking, summarization, and question-answer to achieve their goal (Paul, \& Elder, 2019). They attribute their failure to faulty approaches adopted by them for learning that lead to their efforts being fruitless and make efforts to come up with better approaches in their future endeavors (

\section{Students' beliefs about intelligence and academic domains}

Students hold different beliefs about their intelligence across academic domains (Costa \& Faria 2018) because these specific domain beliefs are predictors of attributions, goals, and academic performance (Costa, \& Faria, 2018). Research also indicates that students can possess various intelligence beliefs for various academic domains (Lou, \& Noels, 2019).

In mathematics mostly students hold entity beliefs. Students with these beliefs think they have fixed math abilities. They think they can do not much to enhance their ability in this particular subject. At the same time, they may hold incremental beliefs about other subjects for example by regularly reading literature and other reading materials such as newspapers, magazines, and journals to improve their vocabulary or reading comprehension (Stump, 2009). Research shows the impact of different subjects on academic achievement (Chen \& Tutwiler, 2017; Priess- Groben \& Hyde, 2017).

\section{Intelligence and Academic Achievement}

Student's beliefs about the implicit theory of intelligence whether intelligence is incremental, or entity significantly affect their academic outcomes (Bostwick et al., 2017). Research shows a significant relationship between students' implicit theory of intelligence and their academic achievement (Mullensiefen et al., 2015). Students having strong beliefs regarding the incremental theory of intelligence tend to show high academic involvement (Tang, Wang, Guo, \& Salmela-Aro, 2019), and overwhelming specific domain deficits (Alesi et al., 2016). Students who believe in incremental intelligence get higher mathematics scores in each semester while students holding entity beliefs do not show the same level of improved results (Sisk, et al, 2018). Students who hold entity beliefs show low academic achievement (Karlen, Suter, Hirt, \& Merki, 2019).

\section{Intelligence and Gender}

Given gender differences, mostly girls are associated with having entity beliefs of intelligence (Diaconu-Gherasim, Tepordei, Mairean, \& Rusu, 2019). According to Heyder, Weidinger, Cimpian, and Steinmayr, (2020) girls indicated stronger beliefs in fixed or entity theory of intelligence when comparing high-achieving students. However, some research studies indicate no gender differences in entity and incremental theorists in terms of academic achievement (Costa, \& Faria, 2018). Females with an 'entity' view have been shown less interested in taking mathematics as a major subject for their career (Burkley et al., 2010). Interestingly students of mathematics as compared to other subjects believe in the fixed and inherited nature of intelligence (Mascret et al., 2015). Students with higher test scores in mathematics and the English language tend to have more 'incremental' beliefs about intelligence. Besides, students with an 'incremental' belief in intelligence report greater achievement at higher grades (Claro \& Loeb, 2017).

\section{METHODOLOGY}

This study adopted a descriptive, correlational research design. Quantitative, descriptive designs are often useful in establishing clear associations between variables. Besides, quantitative designs provide concrete data, generalizable results, and replicable research studies (Gay, Mills, \& Airasian, 2011). The research sites consisted of public-sector universities in Khyber Pakhtunkhwa, Pakistan from where participants were selected. Sample of the study comprised of M.Sc. Mathematics students from public sector universities that offered M.Sc. mathematics. Out of the nine universities that offered the M.Sc. mathematics programs, five universities were randomly selected. From these selected universities, a sample of 450 (302 male and 148 female) students of the M.Sc. mathematics program was taken as a sample. The sample was taken using a multistage random sampling technique.

\section{Measures}

For measuring students' beliefs about intelligence, a questionnaire was used. The questionnaire consisted of 12 items following a five-point scale ranging from Strongly-Disagree (1) to Strongly-Agree (5). The scale was adapted from Dweck (1999). Eight out of the twelve items were taken from Dweck (1999) after the author's permission through email while the remaining four items were by the researchers. Seven items were related to participants' beliefs regarding intelligence as a Fixed ('Entity') and the other five indicated participants' beliefs regarding intelligence as Malleable ('Incremental'). The 
items for 'incremental' and 'entity' intelligence were kept separate. All the items were merged in one scale with half of the items having reverse scores. A pilot study was conducted to establish the validity and the reliability, and practicability of the research instrument. For conducting the pilot study 40 participants were randomly selected from the University of COMSATS, Abbottabad. The calculated value of Cronbach's alpha coefficient was found to be 0.97 . This indicated that the internal reliability of the items was quite good. The previous examination results of the participants from their respective institutions were used as indicators of their academic achievement.

\section{Data collection and analysis}

After securing the consent of participants, the scale was administered for data collection. Pearson correlation analysis was used to find out the relationship of participants' beliefs about intelligence and their academic achievement. Gender differences in academic achievement and beliefs about intelligence were calculated using a t-test.

\section{RESULTS}

The results of the study are presented in the following tables:

Table 1: Relationship of students' beliefs about 'incremental' and 'entity' intelligence with their academic achievement

\begin{tabular}{lll}
\hline Variable & Correlation $(\boldsymbol{r})$ & $\boldsymbol{P}$ \\
\hline 'Incremental' beliefs about intelligence and Achievement & $0.686^{* *}$ & 0.00 \\
'Entity' beliefs about intelligence and Achievement & & \\
& -.447 & 0.00
\end{tabular}

$* * P<0.05$

Table 1 shows significant relationship between students' beliefs about 'incremental' intelligence and achievement $(r=0.686$, $\mathrm{p}<0.05)$. The result shows that students who hold incremental beliefs about their intelligence lead to high academic achievement. No significant correlation $(r=-.447, p>0.05)$ was found between students' 'entity' beliefs about intelligence and their academic achievement. It indicates that students having entity about intelligence shows no significant difference in their academic scores.

Table 2: Gender Differences in beliefs about intelligence

\begin{tabular}{lllllll}
\hline Gender & N & M & SD & SE Mean & $\boldsymbol{t}$ & $\boldsymbol{P}$ \\
\hline Boys & 272 & 40.50 & 12.62 & 0.765 & & \\
Girls & 122 & 37.14 & 13.35 & 1.209 & 2.40 & $0.017^{*}$ \\
\hline
\end{tabular}

$* P<0.05$

The results in Table 2 indicate significant gender differences in their beliefs about intelligence. The value of $t$ is 2.40 , which is more than the tabulated value (1.96) at 0.05 , level shows that male students have more beliefs in 'incremental' intelligence as compared to female students. Female students hold an 'entity' view of intelligence in the subject of mathematics.

Table 3: Gender Differences in academic achievement

\begin{tabular}{lllllll}
\hline Gender & N & M & SD & SE Mean & $\boldsymbol{t}$ & $\boldsymbol{P}$ \\
\hline Boys & 272 & 70.27 & 10.81 & 0.65 & 2.55 & $0.01^{*}$ \\
& & & & 0.94 & & \\
Girls & 122 & 67.28 & 10.47 & & & \\
\hline
\end{tabular}

$* P>0.05$

Table 3 indicates a significant gender difference in academic achievement (value of $t$ is 2.55). The academic achievement in the subject of mathematics of girls is significantly lower than that of boys.

\section{DISCUSSION}

Students' beliefs about their intelligence can be divided into incremental and entity beliefs. The former is the belief that intelligence can be improved with effort and practice and is changeable while the latter is the belief that intelligence is a fixed entity and cannot be changed with effort and hard work. These beliefs have significant implications on student's motivation and learning.

When comparing gender differences in Incremental and Entity beliefs about intelligence, several researchers argued that in mathematics, female students tend to adopt the entity beliefs about their intelligence when compared with the incremental 
beliefs. Similarly, male students were found to have better academic performance holding an incremental belief of intelligence, while female students in the same age group were more likely to hold an entity view of intelligence (van Aalderen-Smeets, \& van der Molen, 2018).

This study explored a possible association between students' beliefs about intelligence and their academic achievement. Results of the study indicated a positive significant relationship between students' academic achievement and their beliefs in incremental intelligence (Gunderson, et al, 2018). No significant relationship was found between students' beliefs about 'entity' intelligence and their academic achievement. These findings are in line with the findings of Costa, and Faria,(2018); Bandura (1977); Devers, (2015); and Jones et al., (2009). Results of these studies found that students having strong beliefs in intelligence as an 'incremental' ability have better academic performance as compared to those who hold 'entity' beliefs about intelligence. Claro, et al., (2016) and Renaud-Dubé, et al., (2015) also have found that at every level of socioeconomic status students having an 'incremental' view of intelligence perform significantly better than those having 'entity' view. Studies conducted in the Australian context also showed a positive relationship of students' 'incremental' beliefs of intelligence with their academic outcomes (Tarbetsky, et al., 2016).

Results of this study also revealed a significant gender difference in students' Incremental and Entity beliefs about intelligence and its impact on their academic achievement. A study showed that male students' academic performance is better in mathematics as compared to female students, Female tended to hold an entity belief of intelligence as compared to male. This finding reinforces the findings of Macnamara, and Rupani, (2017), and Boyle et al. (2010) who found significant differences in male and female students' beliefs about intelligence. However, it must be considered that the study has a particular context i.e., it is based in a semi-urban Pakistani society. This contextual background of the study may have implications for the generalization and understanding of its results. Both the formation of beliefs about intelligence and the possible role of gender in terms of academic achievement needs to be considered in this particular background. Generalization of the study results may, therefore, be restricted to this and other areas of similar socio-cultural backgrounds.

\section{CONCLUSION AND IMPLICATIONS}

From the findings of this study, it can be concluded that students' 'incremental' beliefs in intelligence are associated with better academic achievement as compared to students' beliefs in 'entity' intelligence. In terms of gender, male students perform significantly better in mathematics as compared to their female counterparts. This study has important implications for teachers as they can promote in students a greater desire to learn. These insights may be useful for policymakers and stakeholders in helping them to make better policies regarding the use of incremental intelligence which may have a positive impact on students' academic performance at the university level.

\section{RECOMMENDATIONS}

This study highlights the importance of students' beliefs regarding the nature of intelligence. This study indicates that an 'incremental' belief in intelligence enhances students' determination in the face of difficulties and promotes their desire for learning. Holding an 'incremental' view may be useful to students in educational settings in Pakistan and beyond. Teaching students to adopt an 'incremental' view may lead them to increase their academic achievement. It is, therefore, recommended that teachers focus on bringing relevant changes in students' beliefs regarding intelligence i.e. a shift from an 'entity' view to 'incremental' one. Teachers may create patterns of feedback to stimulate students' achievement goals, promote the learning process, increase their motivation and encourage students to ensure that abilities and intelligence can be enhanced through constant effort.

This study also indicates that female students had more 'entity' beliefs about the nature of intelligence than male students; therefore, it might be very useful for teachers and educators to come up with strategies and plans to augment 'incremental' theories of intelligence among female students. It is recommended that training programs may be arranged for teachers with a focus on how to help their students in their shift towards 'incremental' ability enhancement. The students of postgraduate programs in mathematics subject may be tempted that by working hard they can improve their abilities and achievement.

\section{LIMITATIONS OF THIS STUDY}

There are of course some limitations in the current study. One of the limitations was the number of female participants, there were 148 females only. The reason may be, mostly in our culture females are not encouraged at an early age for learning mathematics, segregated schools with math teachers, cultural differences, limited educational opportunities at the college and university level, and limited choices concerning future professions and career advancements in many cases. This reduced number of female participants limiting the scope of the study. Another limitation was the measure of academic achievement. The measure of academic achievement for this study was cumulative grade point average only.

\section{AUTHOR'S CONTRIBUTIONS}

Dr. Sadaf Naz is the primary author of this research paper. This research paper is a part of her doctoral thesis. 
Dr. Muhammad Ilyas has helped in the data interpretation and discussion part.

Dr. Syed Afzal Shah has helped in data interpretation and discussion.

Anjum Qayum has contributed to revising the literature review of the paper.

\section{REFERENCES}

1. Ajzen, I. (2020). The theory of planned behavior: Frequently asked questions. Human Behavior and Emerging Technologies, 2(4), 314-324. https://doi.org/10.1002/hbe2.195

2. Alesi, M., Rappo, G., \& Pepi, A. (2016). Investigating the improvement of decoding abilities and working memory in children with incremental or entity personal conceptions of intelligence: two case reports. Frontiers in psychology, 6, 1939. https://doi.org/10.3389/fpsyg.2015.01939

3. Aydin, H., Ozfidan, B., \& Carothers, D. (2017). Meeting the challenges of curriculum and instruction in school settings in the United States. Journal of Social Studies Education Research, 8(3), 76-92.

4. Bandura, A. (1977). Social learning theory. Englewood Cliffs, NJ: Prentice-Hall.

5. Barkley, E. F., \& Major, C. H. (2020). Student engagement techniques: A handbook for college faculty. John Wiley \& Sons.

6. Bostwick, K., Collie, R., Martin, A., and Durksen, T. (2017). Students' growth mindsets, goals, and academic outcomes in mathematics. Zeitschrift Psychol, 225, 107-116. https://doi.org/10.1027/2151-2604/a000287

7. Boyle, G. J., Neumann, D. L., Furedy, J. J., \& Westbury, H. R. (2010). Combining the methods of differential and experimental psychology to study sex differences in human cognitive psychological functions. Perceptual and Motor Skills, 110, 392-410. https://doi.org/10.2466/pms.110.2.396-410

8. Brandon, P. S., Lombardi, P., \& Shen, G. Q. (Eds.). (2017). Future challenges in evaluating and managing sustainable development in the built environment. Wiley Blackwell. https://doi.org/10.1002/9781119190691

9. Burkley, M., Parker, J., Stermer, S.P., \&Burkley, E. (2010). Trait Beliefs that Make Women Vulnerable to Math Disengagement. Personality and Individual Differences, 48(2), 234-238. https://doi.org/10.1016/j.paid.2009.09.002

10. Chen, J. A., and Tutwiler, M. S. (2017). Implicit theories of ability and self-efficacy: testing alternative social cognitive models to science motivation. Zeitschrift Psychol, 225, 127-136. https://doi.org/10.1027/21512604/a000289

11. Chen, W. W., \& Wong, Y. L. (2015). Chinese mindset: theories of intelligence, goal orientation and academic achievement in Hong Kong students. Educational Psychology, 35(6), 714-725. https://doi.org/10.1080/01443410 .2014 .893559

12. Claro, S \& Loeb, S. (2017). New evidence that students' beliefs about their brains drive learning. Evidence Speaks Reports, 2(29), 1-7.

13. Claro, S., Paunesku, D., \& Dweck. C.S. (2016). Growth mindset tempers the effects of poverty on academic achievement, Proceedings of the National Academy of Sciences, 113, 8664-8. https://doi.org/10.1073/pna .1608207113

14. Costa, A., Faria, L., (2018). Implicit Theories of Intelligence and Academic Achievement: A Meta-Analytic Review. Frontiers in Psychology, 9. 1-16. https://doi.org/10.3389/fpsyg.2018.00829

15. De Castella, K., \& Byrne, D. (2015). My intelligence may be more malleable than yours: The revised implicit theories of intelligence (self-theory) scale is a better predictor of achievement, motivation, and student disengagement. European Journal of Psychology of Education, 30(3), 245-267. https://doi.org/10.1007/s10212-0150244-y

16. Dejonge, M. L., Omran, J., Faulkner, G. E., \& Sabiston, C. M. (2020). University students' and clinicians' beliefs and attitudes towards physical activity for mental health. Mental Health and Physical Activity, 18, 100316. https://doi.org/10.1016/j.mhpa.2019.100316

17. Devers, A. (2015). Thinking about Intelligence: How Student Mindsets Influence Academic Performance. Rising Tide, 7, 1-23.

18. Diaconu-Gherasim, L. R., Tepordei, A. M., Mairean, C., \& Rusu, A. (2019). Intelligence beliefs, goal orientations and children's academic achievement: does the children's gender matter? Educational Studies, 45(1), 95-112. https://doi.org/10.1080/03055698.2018.1443796

19. Dweck, C. S. (1988). Goals: An approach to motivation and achievement. Journal of personality and Social Psychology, 54(1), 5-12. https://doi.org/10.1037/0022-3514.54.1.5

20. Dweck, C. (1999). Self-theories: their role in motivation, personality, and development. Philadelphia: Psychology Press.

21. Eccles, J. S., \& Wigfield, A. (2020). From expectancy-value theory to situated expectancy-value theory: A developmental, social cognitive, and sociocultural perspective on motivation. Contemporary Educational Psychology, 61, 101859. https://doi.org/10.1016/j.cedpsych.2020.101859 
22. Ferla, M., \& Graham, A. (2019). Women slowly taking off: An investigation into female underrepresentation in commercial aviation. Research in Transportation Business \& Management, 31, 100378. https://doi.org/10.1016/ j.rtbm.2019.100378

23. Fitri, S., Syahputra, E., \& Syahputra, H. (2019). Blended learning rotation model of cognitive conflict strategy to improve mathematical resilience in high school students. International Journal of Scientific \& Technology Research, 1(1), 80-87.

24. Gay, L.R., Mills, G.E. and Airasian, P. (2011). Educational Research Competencies for Analysis and Applications. Pearson, Columbus.

25. Gunderson, E. A., Park, D., Maloney, E. A., Beilock, S. L., \& Levine, S. C. (2018). Reciprocal relations among motivational frameworks, math anxiety, and math achievement in early elementary school. Journal of Cognition and Development, 19(1), 21-46. https://doi.org/10.1080/15248372.2017.1421538

26. Haimovitz, K., \& Dweck, C. S. (2017). The origins of children's growth and fixed mindsets: New research and a new proposal. Child development, 88(6), 1849-1859. https://doi.org/10.1111/cdev.12955

27. Hava, K., Guyer, T., \& Cakir, H. (2020). Gifted students' learning experiences in systematic game development process in after-school activities. Educational Technology Research and Development, 68(3), 1439-1459. https://doi.org/10.1007/s11423-020-09750-Z

28. Heyder, A., Weidinger, A. F., Cimpian, A., \& Steinmayr, R. (2020). Teachers' belief that math requires innate ability predicts lower intrinsic motivation among low-achieving students. Learning and Instruction, 65, 101220. https://doi.org/10.1016/j.learninstruc.2019.101220

29. Hirsch, A., Bieleke, M., Schüler, J., \& Wolff, W. (2020). Implicit theories about athletic ability modulate the effects of if-then planning on performance in a standardized endurance task. International journal of environmental research and public health, 17(7), 2576. https://doi.org/10.3390/ijerph17072576

30. Hughes, J. S. (2015). Support for the domain specificity of implicit beliefs about persons, intelligence, and morality. Personality and Individual Differences, 86, 195-203. https://doi.org/10.1016/j.paid.2015.05.042

31. Jones, B. D., Byrd, C. N., \& Lusk, D. (2009). High school students' beliefs about intelligence. Research In The Schools, 16(2), 1-14.

32. Karlen, Y., Suter, F., Hirt, C., \& Merki, K. M. (2019). The role of implicit theories in students' grit, achievement goals, intrinsic and extrinsic motivation, and achievement in the context of a long-term challenging task. Learning and Individual Differences, 74, 101757. https://doi.org/10.1016/j.lindif.2019.101757

33. Kassaee, A. M. (2016). Examining the role of motivation and mindset in the performance of college students majoring in STEM fields (Doctoral dissertation, Middle Tennessee State University).

34. Kim, Y. C., \& Jung, J. H. (2019). Conceptualizing shadow curriculum: definition, features and the changing landscapes of learning cultures. Journal of Curriculum Studies, 51(2), 141-161. https://doi.org/10.1080/00220 272.2019.1568583

35. Lee, J. J. (2020). Frame failures and reframing dialogues in the public sector design projects. International Journal of Design, 14(1), 81-94.

36. Lou, N. M., \& Noels, K. A. (2019). Promoting growth in foreign and second language education: A research agenda for mindsets in language learning and teaching. System, 86, 102126. https://doi.org/10.1016/j.system.2019.102126

37. Macnamara, B. N., \& Rupani, N. S. (2017). The relationship between intelligence and mindset. Intelligence, 64, 5259. https://doi.org/10.1016/j.intell.2017.07.003

38. Mak, K. K., \& Pichika, M. R. (2019). Artificial intelligence in drug development: present status and future prospects. Drug discovery today, 24(3), 773-780. https://doi.org/10.1016/j.drudis.2018.11.014

39. Mascret, N., Roussel, P., \& Cury, F. (2015). Using implicit measures to highlight science teachers' implicit theories of intelligence. European journal of psychology of education, 30(3), 269-280. https://doi.org/10.1007/s10212-015$0249-6$

40. Moe, A., Hausmann, M., \& Hirnstein, M. (2021). Gender stereotypes and incremental beliefs in STEM and nonSTEM students in three countries: Relationships with performance in cognitive tasks. Psychological research, 85(2), 554-567. https://doi.org/10.1007/s00426-019-01285-0

41. Mofield, E. L., \& Parker Peters, M. (2018). Mindset misconception? Comparing mindsets, perfectionism, and attitudes of achievement in gifted, advanced, and typical students. Gifted Child Quarterly, 62(4), 327-349. https://doi.org/10.1177/0016986218758440

42. Mullensiefen, D., Harrison, P., Caprini, F., \& Fancourt, A. (2015). Investigating the importance of self-theories of intelligence and musicality for students' academic and musical achievement. Frontiers in psychology, 6, 1702. https://doi.org/10.3389/fpsyg.2015.01702

43. Mundy, L. (2012). The richer sex. Time, 179(12), 28-34.

44. OKeefe, P. A., Dweck, C. S., \& Walton, G. M. (2018). Implicit theories of interest: Finding your passion or developing it?. Psychological Science, 29(10), 1653-1664. https://doi.org/10.1177/0956797618780643 
45. Ortiz Alvarado, N. B., Rodriguez Ontiveros, M., \& Ayala Gaytán, E. A. (2019). Do mindsets shape students' wellbeing and performance?. The Journal of psychology, 153(8), 843-859. https://doi.org/10.1080/00223980 .2019.1631141

46. Paul, R., \& Elder, L. (2019). The miniature guide to critical thinking concepts and tools. Rowman \& Littlefield.

47. Peng, M. Y. P., \& Chen, C. C. (2019). The effect of instructor's learning modes on deep approach to student learning and learning outcomes. Educational Sciences: Theory \& Practice, 19(3),65-85.

48. Price, R. B. E. (2021). Nietzsche, Heidegger and Colonialism: Occupying South East Asia (Vol. 85). Routledge. https://doi.org/10.4324/9781003090618

49. Priess-Groben, H., and Hyde, J. (2017). Implicit theories, expectancies, and values predict mathematics motivation and behavior across high school and college. J. Youth. Adolescence. 46, 1318-1332. https://doi.org/10.1007 /s10964-016-0579-y

50. Redding, C. (2019). A teacher like me: A review of the effect of student-teacher racial/ethnic matching on teacher perceptions of students and student academic and behavioral outcomes. Review of Educational Research, 89(4), 499-535. https://doi.org/10.3102/0034654319853545

51. Renaud-Dubé, A., Guay, F., Talbot, D., Taylor, G., \& Koestner, R. (2015). The relations between implicit intelligence beliefs, autonomous academic motivation, and school persistence intentions: A mediation model, Social Psychology of Education, 18, 255-72. https://doi.org/10.1007/s11218-014-9288-0

52. Rissanen, I., Kuusisto, E., Hanhimäki, E., \& Tirri, K. (2018). The implications of teachers' implicit theories for moral education: A case study from Finland. Journal of Moral Education, 47(1), 63-77. https://doi.org/10.1080 /03057240.2017.1374244

53. Savage, G. C., \& Lewis, S. (2018). The phantom national? Assembling national teaching standards in Australia's federal system. Journal of Education Policy, 33(1), 118-142. https://doi.org/10.1080/02680939.2017.1325518

54. Savage, J. E., Jansen, P. R., Stringer, S., Watanabe, K., Bryois, J., De Leeuw, C. A., ... \& Posthuma, D. (2018). Genome-wide association meta-analysis in 269,867 individuals identifies new genetic and functional links to intelligence. Nature genetics, 50(7), 912-919. https://doi.org/10.1038/s41588-018-0152-6

55. Sisk, V. F., Burgoyne, A. P., Sun, J., Butler, J. L., \& Macnamara, B. N. (2018). To what extent and under which circumstances are growth mind-sets important to academic achievement? Two meta-analyses. Psychological science, 29(4), 549-571. https://doi.org/10.1177/0956797617739704

56. Stump, G., Husman, J., Chung, W. T., \& Done, A. (2009, October). Student beliefs about intelligence: Relationship to learning. In 2009 39th IEEE Frontiers in Education Conference (pp. 1-6). IEEE. https://doi.org/10.1109/FIE.2009.5350426

57. Tambe, P., Cappelli, P., \& Yakubovich, V. (2019). Artificial intelligence in human resources management: Challenges and a path forward. California Management Review, 61(4), 15-42. https://doi.org/10.1177/0 $\underline{008125619867910}$

58. Tarbetsky, A. L., Collie, R. J., \& Martin, A. J. (2016). The role of implicit theories of intelligence and ability in predicting achievement for Indigenous (Aboriginal) Australian students. Contemporary Educational Psychology, 47, 61-71. https://doi.org/10.1016/j.cedpsych.2016.01.002

59. Thippana, J., Elliott, L., Gehman, S., Libertus, K., \& Libertus, M. E. (2020). Parents' use of number talk with young children: Comparing methods, family factors, activity contexts, and relations to math skills. Early Childhood Research Quarterly, 53, 249-259. https://doi.org/10.1016/j.ecresq.2020.05.002

60. Thomas, A.J., \& Sarnecka, B.W. (2015). Exploring the relation between people's theories of intelligence and beliefs about brain development, Frontiers in Psychology, 6, 1-12. https://doi.org/10.3389/fpsyg.2015.00921

61. Todor, I. (2014). Investigating "the old stereotype" about boys/girls and mathematics: Gender differences in implicit theory of intelligence and mathematics self-efficacy beliefs. Procedia-Social and Behavioral Sciences, 159, 319-323. https://doi.org/10.1016/j.sbspro.2014.12.380

62. Tondeur, J., Van Braak, J., Ertmer, P. A., \& Ottenbreit-Leftwich, A. (2017). Understanding the relationship between teachers' pedagogical beliefs and technology use in education: a systematic review of qualitative evidence. Educational technology research and development, 65(3), 555-575. https://doi.org/10.1007/s11423-0169481-2

63. Vahalíková, E. (2013). The Relationship between Mind Sets and the Motivation of secondary School Students of English as a second Language (Doctoral dissertation, Dissertation). Masaryk University. Retrieved from https://is. muni. cz/th/270621/ff_m).

64. van Aalderen-Smeets, S. I., \& van der Molen, J. H. W. (2018). Modeling the relation between students' implicit beliefs about their abilities and their educational STEM choices. International journal of technology and design education, 28(1), 1-27. https://doi.org/10.1007/s10798-016-9387-7

65. Vincent-Ruz, P., \& Schunn, C. D. (2017). The increasingly important role of science competency beliefs for science learning in girls. Journal of Research in Science Teaching, 54(6), 790-822. https://doi.org/10.1002/tea.21387 
66. Wren, D. A., \& Bedeian, A. G. (2020). The evolution of management thought. John Wiley \& Sons.

67. Yeager, D. S., Hanselman, P., Walton, G. M., Murray, J. S., Crosnoe, R., Muller, C., ... \& Dweck, C. S. (2019). A national experiment reveals where a growth mindset improves achievement. Nature, 573(7774), 364-369. https://doi.org/10.1038/s41586-019-1466-y 